\title{
DCH18C6 USING STRONTIUM EXTRACTION SELECTIVITY INVESTIGATION AND SEQUENTIAL SOIL FRACTIONATION STUDY
}

\author{
GABRIELA PISARČÍKOVÁ ${ }^{1}$, LUCIA ZÁVODSKÁ \\ JURAJ LESNÝ ${ }^{1}$ \\ ${ }^{1}$ Department of Biotechnology, University of SS. Cyril and Methodius, J. Herdu 2, \\ Trnava, SK-917 01, Slovak Republic (pisarcig@ucm.sk) \\ ${ }^{2}$ Department of Projecting \& Nuclear and Radiation Safety, Ekosur, Jaslovské \\ Bohunice, SK-919 31, Slovak Republic (zavodska@ekosur.sk)
}

\begin{abstract}
Sr}$ as radioindicator has been applied to strontium separation selectivity study using cisdicyclohexano-18-crown-6 (DCH18C6) as extraction agent and picric acid as counter ion with the aim to contribute to the development of a rapid method of strontium extraction. The same radioindicator has been used for strontium fractionation study in chosen soils by application of Tessier- and BCR sequential extraction procedures. Experimental results have shown, that the mentioned extraction system is applicable for IDA determination of $\mathrm{Sr}^{2+}$ in $\sim 1000$-fold abundance of $\mathrm{Ca}^{2+}, \sim 1000$-fold abundance and $\mathrm{Mg}^{2+}, \sim 10$-fold abundance of $\mathrm{K}^{+}$and $\sim 0.2$-fold abundance of $\mathrm{Ba}^{2+}$. For the soil samples - chernozems developed on loess from the near vicinity of NPP Jaslovské Bohunice the exchangeable strontium fraction reached as much as $50-60 \%$.
\end{abstract}

Key words: strontium, separation, solvent extraction, crown ethers

\section{Introduction}

Strontium-90 is one of the most hazardous components of radioactive fallout. It is produced essentially by the ${ }^{235} \mathrm{U}$ and ${ }^{239} \mathrm{Pu}$ nuclear fission reactions and has been emitted mainly to the atmosphere via nuclear weapon tests and nuclear reactor accidents. Owing to its chemical and biochemical similarity to calcium, more than $99 \%$ of strontium is efficiently incorporated into bone tissue and teeth. Characterized by long physical- and effective half-lives ${ }^{90} \mathrm{Sr}$ may cause damage to bone marrow by means of its $\beta^{-}$particles $\left(E_{\beta}=0.546 \mathrm{MeV}\right)$ as well as $\beta^{-}$particles of its daughterradionuclide, namely ${ }^{90} \mathrm{Y}\left(\mathrm{E}_{\beta}=2.273 \mathrm{MeV}\right)$ (BRUN et al., 2003).

Numerous methods have been described for the determination of radiostrontium in biological and environmental samples. An essential step in all of these methods is the selective separation of strontium, both to remove radionuclides which may interfere with subsequent $\beta$-counting and to free it from the large quantities of inactive substances typically present. The most significant of these inert constituents is usually calcium, which presents a special problem because it follows strontium in most chemical reactions (BOJANOWSKI and SKIBA, 1990; HORWITZ et al., 1991).

Classical methods for the separation of strontium (fuming nitric acid method, cation-exchange method, extraction method using HDEHP or TBP, etc.) are time- and labor-consuming, they namely include many stages of chemical sample preparation, 
and, to carry out the measurements, the time of about 2 weeks is required to obtain the equilibrium of ${ }^{90} \mathrm{Sr}-{ }^{90} \mathrm{Y}$ mixtures (GUOGANG, 1994; ANDRYUSHCHENKO et al., 2003; JAKOPIČ and BENEDIK, 2005).

Macrocyclic crown ethers are known as selective ligands for various ions (IZATT et al, 1991, GHASEMI et al., 2005). The use of macrocyclic polyethers for the separation of strontium has been proposed as well (BLASIUS et al., 1985; HORWITZ et al., 1991).

Dicyclohexano-18-crown-6 forms with alkaline metal- and alkaline-earth metal ions complexes of different stability. In this work the selectivity of $\mathrm{Sr}^{2+}$ separation by means of Sr-DCH18C6 complex has been studied. The results of Tessier- and BCR sequential soil fractionation serve to assess the possibility of strontium separation from potentially ${ }^{90} \mathrm{Sr}$-contamined soil samples.

\section{Material and methods}

\subsection{Reagents}

All the chemicals used were of analytical reagent grade. The stock solution of the relevant crown ether in chloroform was prepared from DCH18C6 - a mixture of cissyn-cis and cis-anti-cis isomers purchased from ACROSS ORGANICS (Ceel, Belgium). Aqueous solutions of picric acid were prepared using the relevant reagent (Merck, Darmstadt, Germany). All aqueous solutions have been prepared using ultrapure deionized water $\left(0.054 \mu \mathrm{S} \mathrm{cm}^{-1}\right)$. Solutions of interfering cations $\left(\mathrm{Ca}^{2+}, \mathrm{Ba}^{2+}\right.$, $\mathrm{Mg}^{2+}, \mathrm{K}^{+}$) were prepared from their commercial salts. Sodium citrate and hydrochloric acid of proper concentrations were used as buffer solutions. The radioindicator etalon solution $-{ }^{85} \mathrm{SrCl}_{2}$ of known specific activity $\left(106.6 \mathrm{kBq} \mathrm{g}^{-1}\right)$ and of known chemical concentration $\left(20 \mathrm{mg} \mathrm{dm}^{-3}\right.$ diluted in $3 \mathrm{~g} \mathrm{dm}^{-3} \mathrm{HCl}$ ) was obtained from the Czech Metrology Institute (Prague, Czech Republic). The Tessier- and BCR sequential extractions have been performed using the normalized chemical reagents, namely $\mathrm{MgCl}_{2}, \mathrm{NaOAc}, \mathrm{NH}_{4} \mathrm{OAc}, \mathrm{HOAc}, \mathrm{NH}_{2} \mathrm{OH} \cdot \mathrm{HCl}, \mathrm{HNO}_{3}$ and $\mathrm{H}_{2} \mathrm{O}_{2}$ (Lachema, Czech Republic).

\subsection{Samples}

Two soil samples, namely chernozems developed on loess (soil horizon $0-5 \mathrm{~cm}$ and $10-20 \mathrm{~cm}$ ), and montmorillonite K-10 (Aldrich) were investigated by sequential extractions. The soil samples were collected from near vicinity of NPP Jaslovské Bohunice. They are typical ones for the relevant region. Soil samples were air dried and sieved. Only the size-fraction less than $2 \mathrm{~mm}$ has been taken into experiments.

\subsection{Extraction procedure}

Solvent extraction experiments were performed in $20 \mathrm{~cm}^{3}$ glass vessels. As initial volumes of aqueous and organic phases $2.5 \mathrm{~cm}^{3}$ have been chosen. The extraction 
mixtures were shaken using a laboratory shaker at $25^{\circ} \mathrm{C}$. After the phases were allowed to separate $1 \mathrm{~cm}^{3}$ of both aqueous and organic phases was taken. Using a gamma spectrometric detection assembly the counting rate in all of the resulting solutions has been measured. All analytical procedures have been carried out in three replicate experiments.

\subsection{Sequential extractions}

The fractional analyses have been performed by means of the Tessier- and BCR procedures (TESSIER et al., 1979; GLEYZES et al., 2002). Both of them were slightly modified at the beginning, namely by completing the given procedures by a starting extraction step with rainwater collected from the near vicinity of NPP Jaslovské Bohunice. The value of the residual fraction was calculated from the difference of the starting count rate of the labelled solid sample and the sum of that ones of partial fractions. For BCR procedure, besides the rainfall- and the residual fractions, only the exchangeable and the reducible ones have been measured because of the expected radioactivity fractionation. The chemical concentration of the used radioindicator was considered as carrier less.

\subsection{Radiometric analysis}

For radiometric determinations of ${ }^{85} \mathrm{Sr}$ in water- and organic phases the gamma spectrometric scintillation detector 54BP54/2-X with the well type crystal $\mathrm{NaI}(\mathrm{Tl})$ (Scionix, Netherlands) and the data processing software Scintivision32 (Ortec, USA) were used. The counting time $400 \mathrm{~s}$ was sufficient for obtaining data with the relative detection error $<2 \%$.

\section{Results and discussion}

In order to establish the best extraction conditions a detailed study of the relevant separation parameters was performed. The parameters chosen were: phase contact time, extraction medium $\mathrm{pH}$, concentration of crown ether, concentration of picric acid and the presence of the interfering cations. The results obtained are presented by means of the particular fractions of radioactivity in the organic phase.

\subsection{The effect of the contact time}

To determine the degree of extraction and to establish the rate/kinetic of the investigated process we realized the shaking of aqueous and organic phases for different times, from 2 to 120 minutes. For these experiments the same volumes $(2.5$ $\mathrm{cm}^{3}$ ) of the phases were chosen. The results showed (Fig. 1) that the separation was a very fast process which reached its equilibrium within a few minutes. On the basis of the corresponding measurements, a shaking time of 10 minutes was used for all of the subsequent experiments. 


\subsection{The effect of counter-ion concentration}

The transfer of cationic crown ether complex species across the concerned extraction interphase requires the presence of a suitable counter anion in the separation system. The nature of the counter ion involved plays an important role strongly influencing the extraction efficiency. In respect to the function in question, large organophilic anions, like picrate, tetraphenyl borate and chloroacetate have been found to be quite effective (CHUANG and LO, 1995; KUMAR et al., 1997). In our experiments picrate was used. The complex formation equilibrium in chloroform is defined as

$$
\mathrm{M}_{\text {aq }}^{+}+\mathrm{X}_{\mathrm{aq}}^{-}+\mathrm{L}_{\text {org }} \longrightarrow \mathrm{M}^{+} \mathrm{LX}_{\text {org }}^{-}
$$

where $\mathrm{M}^{+}, \mathrm{X}^{-}$and $\mathrm{L}$ refer to the metal ion, counter anion and crown ether respectively (TALANOVA et al., 1999; KIKUCHI and SAKAMOTO, 2000).

Fig. 1 illustrates the obtained results. The extraction of strontium has been found more efficient when the concentration of picric acid increased. In our further experiments a concentration of $4.36 .10^{-2} \mathrm{M}$ picric acid was used.

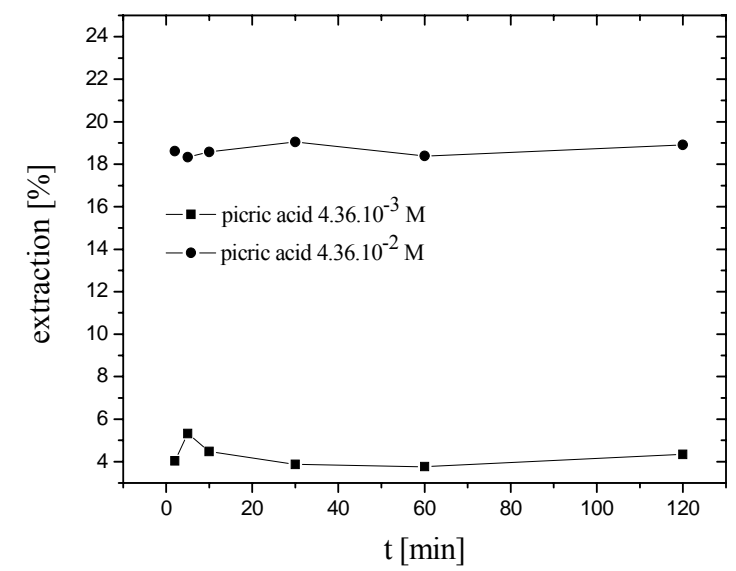

Fig. 1. The effect of contact time and picric acid concentration on the strontium extraction $\left(\mathrm{c}_{\mathrm{Sr} 2+}=1.25 \cdot 10^{-4}\right.$ $\left.\mathrm{M}, \mathrm{c}_{\mathrm{DCH} 18 \mathrm{C} 6}=2 \cdot 5 \cdot 10^{-4} \mathrm{M}, \mathrm{pH}=4.8\right)$.

\subsection{The effect of $p H$}

The assessment of the optimal $\mathrm{pH}$ for the extraction of $\mathrm{Sr}^{2+}$ using $2.5 .10^{-4} \mathrm{M}$ DCH18C6 in chloroform was realized in presence of $4.36 .10^{-3} \mathrm{M}$ picrate ion in $\mathrm{pH}$ values ranged from 2.9 to 4.8 . The effect of $\mathrm{pH}$ on the extraction of strontium is evident from the Fig. 2. As it is evident from Fig. 2, the extraction of $\mathrm{Sr}^{2+}$ into organic phase is strongly $\mathrm{pH}$ dependent. $\mathrm{Sr}^{2+}$ was most effectively extracted in a narrow $\mathrm{pH}$ range, namely from 3.6 to 3.8. An important limitation of each of crown ether based separation procedures is their ineffectiveness for highly acidic sample solutions. Kimura et al., (1979) recommend for strontium extraction the $\mathrm{pH}$ range from 2.5 to 7. 


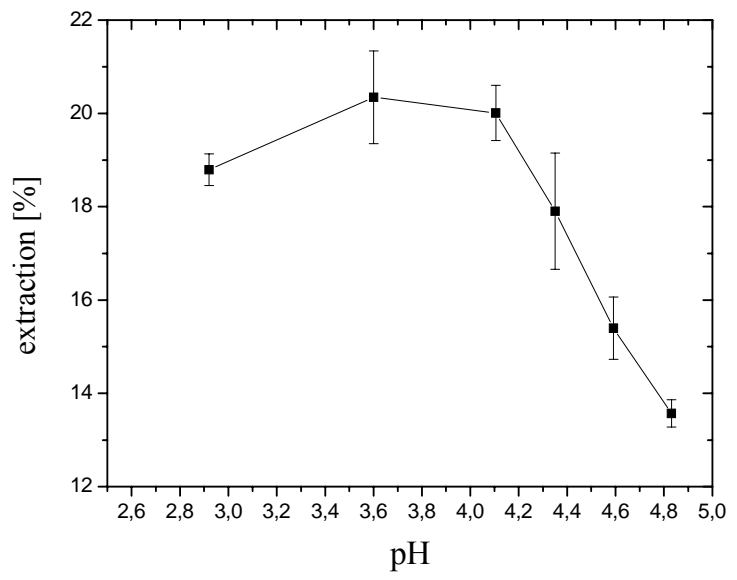

Fig. 2. The effect of $\mathrm{pH}$ on the extraction of strontium $\left(\mathrm{c}_{\mathrm{Sr} 2+}=1.25 \cdot 10^{-4} \mathrm{M}, \mathrm{c}_{\mathrm{DCH} 18 \mathrm{CC} 6}=2.5 \cdot 10^{-4} \mathrm{M}, \mathrm{c}_{\mathrm{C} 6 \mathrm{H} 3 \mathrm{~N} 3 \mathrm{O} 7}=\right.$ $4.36 .10^{-2} \mathrm{M}$ )

\subsection{The effect of interfering cations}

The extraction selectivity of strontium was investigated in presence of various metal ions. The choice of interfering cations was carried out considering the expected size correlation with DCH18C6.

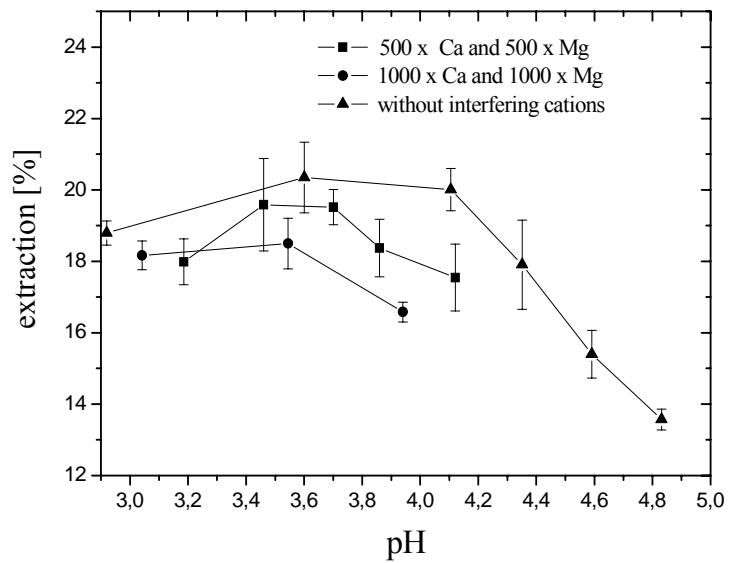

Fig. 3. The effect of presence $\mathrm{Ca}^{2+}, \mathrm{Mg}^{2+}$ on the extraction of strontium $\left(\mathrm{c}_{\mathrm{Sr} 2+}=1.25 .10^{-4} \mathrm{M}, \mathrm{c}_{\mathrm{DCH} 18 \mathrm{C} 6}=\right.$ $\left.2.5 .10^{-4} \mathrm{M}, \mathrm{c}_{\mathrm{C} 6 \mathrm{H} 3 \mathrm{~N} 3 \mathrm{O} 7}=4.36 .10^{-2} \mathrm{M}\right)$.

Our experiments show (Fig. 3) that the presence of $\mathrm{Ca}^{2+}$ and $\mathrm{Mg}^{2+}$ has only a negligible influence on the strontium extraction even at 1000-fold abundance. However, the extraction of $\mathrm{Sr}^{2+}$ decreased significantly in markedly lower abundance of $\mathrm{K}^{+}$and $\mathrm{Ba}^{2+}$ (Fig. 4) Namely, the presence of 50 -fold concentration of $\mathrm{Ba}^{2+}$ resulted in negligible strontium extraction. It should be noted, that the interference effects of 
$\mathrm{Ba}^{2+}$ ions are more apparent in comparison with the $\mathrm{Ca}^{2+}$ and $\mathrm{Mg}^{2+}$ ones. This feature is presumably due to the stronger impact of the favourable ionic radius of $\mathrm{Ba}^{2+}$ to the cavity size of the DCH18C6 than the adequate coincidence of $\mathrm{Ca}^{2+}\left(\mathrm{Mg}^{2+}\right)$. The relevant complexation size compatibility plays apparently a critical role.

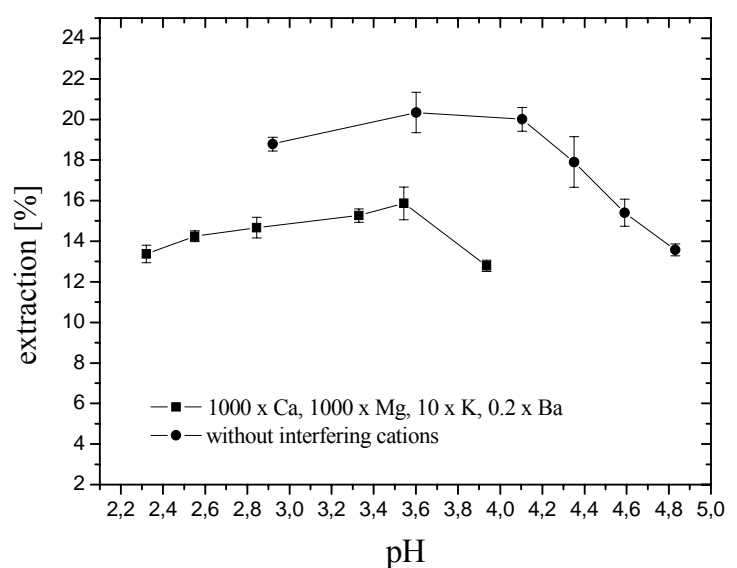

Fig. 4. The effect of presence $\mathrm{Ba}^{2+}, \mathrm{Ca}^{2+}, \mathrm{Mg}^{2+}$ and $\mathrm{K}^{+}$on the extraction of strontium $\left(\mathrm{c}_{\mathrm{Sr} 2+}=1.25 .10^{-4} \mathrm{M}\right.$, $\left.\mathrm{c}_{\mathrm{DCH} 18 \mathrm{C} 6}=2.5 \cdot 10^{-4} \mathrm{M}, \mathrm{c}_{\mathrm{C} 6 \mathrm{H} 3 \mathrm{~N} 3 \mathrm{O} 7}=4.36 .10^{-2} \mathrm{M}\right)$ ).

\subsection{Sequential extractions}

Both, the Tessier- and BCR procedures confirm the expected assumption that the main portion of soil strontium content $(50-60 \%)$ is connected with the exchangeable fraction. In the same time montmorillonite K-10 showed a significantly different behaviour. This fact is evidently caused by highly homogenous surface of it on the contrary with the strongly heterogeneous soil surface.

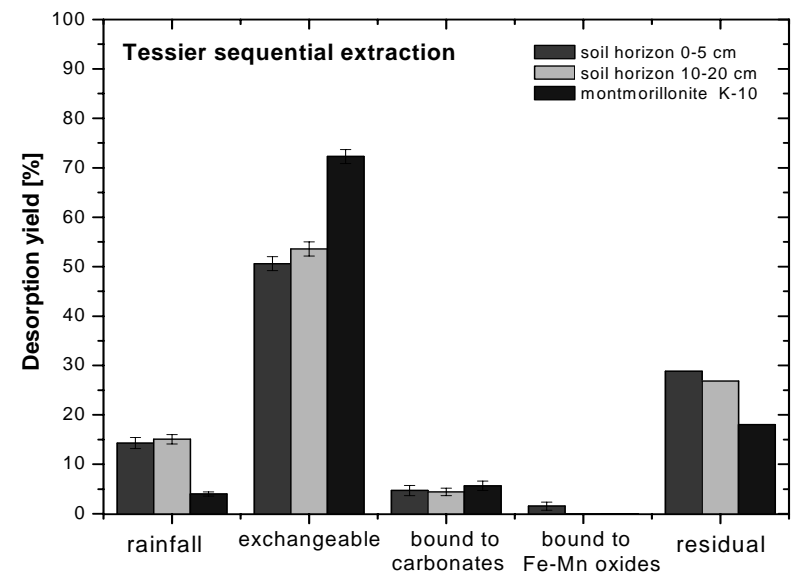

Fig.5: ${ }^{85} \mathrm{Sr}$ fractionation in soil samples and in montmorillonite K-10 using Tessier sequential extraction 


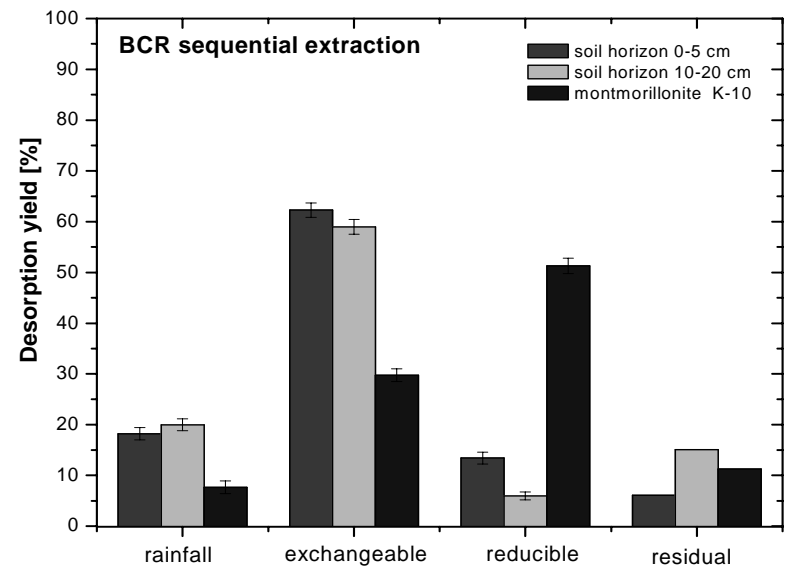

Fig.6: ${ }^{85} \mathrm{Sr}$ fractionation in soil samples and in montmorillonite K-10 using BCR sequential extraction

The newly introduced rainwater step resulted in similarly low values of strontium fractions $(10-20 \%)$ for both of the applied procedures. The aim of this step was to contribute to the assessment of the strontium distribution to the environment immediately after a hypothetic nuclear accident. Such a step serves to bring about a more realistic imitation of natural conditions for the related case.

\section{Conclusions}

The mixture of cis-syn-cis and cis-anti-cis isomers of dicyclohexano-18-crown-6 has been proved as a suitable and commercially available extraction reagent which in optimized reaction system offers an adequate tool for advantageous separation of strontium. By us experimentally specified optimal extraction conditions have been as follows: $\mathrm{c}_{\mathrm{Sr} 2+} \geq 1 \cdot 10^{-4} \mathrm{M}$; chloroform as organic solvent; $\mathrm{c}_{\mathrm{DCH} 18 \mathrm{C} 6}: \mathrm{c}_{\mathrm{C} 6 \mathrm{H} 3 \mathrm{~N} 3 \mathrm{O} 7}: \mathrm{c}_{\mathrm{Sr} 2+}=$ 2 : $350: 1$; contact time $600 \mathrm{~s}$; $\mathrm{pH} 3.6$ - 3.8. Using the above defined conditions, the selectivity of the process studied reached a suitable degree for its applicability in IDA determination of $\mathrm{Sr}^{2+}$, namely in its aqueous solutions in the above indicated concentrations, and in the same time in $\sim 1000$-fold abundance of $\mathrm{Ca}^{2+}, \sim 1000$-fold abundance and $\mathrm{Mg}^{2+}, \sim 10$-fold abundance of $\mathrm{K}^{+}$and $\sim 0.2$-fold abundance of $\mathrm{Ba}^{2+}$.

Both sequential extraction procedures confirmed that the main and quantitatively a not negligible deal of soil strontium is connected to the exchangeable soil fraction. The obtained results support the potential possibility of strontium separation from soil using DCH18C6 for analytical purposes.

\section{References}

ANDRYUSHCHENKO, A.Y., BLANK, A.B., BUDAKOVSKY, S.V., TARASENKO, O.A., SHEVTSOV, N.I.: Sorption-scintillation determination of

${ }^{90} \mathrm{Sr}$ in natural water. Anal. Chim. Acta, 480, 2003, 151-156. 
BLASIUS, E., KLEIN, W., SCHÖN, U.: Separation of strontium from nuclear waste solutions by solvent extraction with crown ethers. J. Radioanal. Nucl. Chem., 89, 1985, 389-398.

BOJANOWSKI, R., SKIBA, D.P.: Determination of low-level ${ }^{90} \mathrm{Sr}$ in environmental materials: A novel approach to the classical method. J. Radioanal. Nucl. Chem., 138, 1990, 207-218.

BRUN, S., KERGADALLAN, Y., BOURSIER B., FREMY, J.M., JANIN, F.: Methodology for determination of radiostrontium in milk: a review. Lait, 83, 2003, $1-15$.

CHUANG, J.T., LO, J.G.: The solvent extraction of carrier-free ${ }^{90} \mathrm{Y}$ from ${ }^{90} \mathrm{Sr}$ with crown ether. J. Radioanal. Nucl. Chem., 189, 1995, 207-317.

GHASEMI, J., NIKRAHI, A., NIAZI, A.: Extraction-Spectrophotometric Determination of Trace Amounts of Barium and Strontium by 18-Crown-6 and Rose Bengal Using Partial Least Squares. Turk. J. Chem., 29, 2005, 669-678.

GLEYZES, CH., TELLIER, S., ASTRUC, M.: Fractionation studies of trace elements in contaminated soils and sediments: a review of sequential extraction procedures. Trends Anal. Chem., 21, 2002, 451-467.

GUOGANG, J.: A rapid and accurate method for the determination of strontium-90 in environmental soil. J. Radioanal. Nucl. Chem., 185, 1994, 255-264.

HORWITZ, E.P., DIETZ, M.L., FISHER, D.E.: Separation and Preconcentration of Strontium from Biological, Environmental, and Nuclear Waste Samples by Extraction Chromatography Using a Crown Ether. Anal. Chem., 63, 1991, 522525.

IZATT, R.M., PAWLAK, L., BRADSHAW, J.S., BRUENING, R.L.: Thermodynamic and kinetic data for macrocycle interactions with cations and anions. Chem. Rev., 91, 1991, 1721-2085.

JAKOPIČ, R., BENEDIK, L.: Tracer studies on Sr resin and determination of ${ }^{90} \mathrm{Sr}$ in environmental samples. Acta Chim. Slov., 52, 2005, 297-302.

KIKUCHI, Y., SAKAMOTO, Y.: Complex formation of alkali metal ions with 18crown-6 and its derivates in 1,2-dichlorethane. Anal. Chim. Acta, 403, 2000, 325 332.

KIMURA, T., IWASHIMA, K., ISHIMORI, T., HAMADA, T.: Separation of strontium-89 and -90 from calcium in milk with a macrocyclic ether. Anal. Chem., 51, 1979, 1113-1116.

KUMAR, A., MOHAPATRA, P.K., PATHAK, P.N., MANCHANDA, V.K.: Dicyclohexano 18 crown 6 in butanol-octanol mixture: A promising extractant of Sr(II) from nitric acid medium. Talanta, 45, 1997, 387-395.

TALANOVA, G.G., ELKARIM, N.S.A., TALANOV, V.S., HANES, R.E., HWANG, H.-S., BARTSCH, R.A., ROGERS, R.D.: The "picrate effect" on extraction selectivities of aromatic group-containing crown ethers for alkali metal cations. J. Am. Chem. Soc., 121, 1999, 11281-11290.

TESSIER, A., CAMPBELL, P.G.C., BISSON, M.: Sequential extraction procedure for the speciation of particulate trace metals. Anal. Chem., 51, 1979, 844-851. 